United States, the Philippine Islands, and Japan. The ship was in command of Commander Belknap so far as Manila, where he was relieved on account of illness by Lieut.-Commander H. M. Hodges.

As previous surveys had established a satisfactory route so far as the Sandwich Islands, the work of the Nero began at Honolulu, whence the ship sailed on May 6, I899. The instructions were to follow as nearly direct lines as practicable from Honolulu to Midway Island, thence to Guam, and from Guam to Luzon; also from Guam to Japan. Soundings were to be taken on the outward voyage at intervals of ro miles and 2 miles alternately; temperatures of the air, and surface and bottom of the sea to be recorded; currents noted; samples of bottom to be collected and preserved. The return course was planned to cross the primary route zigzag at angles of fortyfive degrees, the sides of the zigzags to be 20 miles in length, and soundings to be taken at the apices. When it is stated that this plan, modified by circumstances chiefly as regards intervals between soundings and detours from the main line in order to develop marked irregularities in the contour of the ocean bed, was effectively carried out, we may agree that the belt 14 miles wide and more than 6000 miles in length has been examined with a thoroughness,

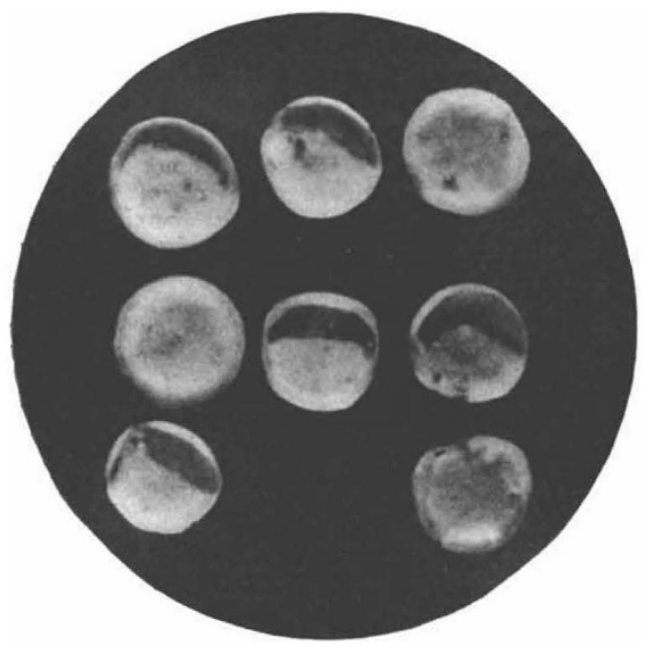

FIG. 1.-Diatom ooze obtained at a depth of 2788 fathoms in latitude $14^{\circ} 24^{\prime} \mathrm{N}$., and long. $135^{\circ} 31^{\prime} \mathrm{E}$. Coscinodiscus rex, Wallich, magnified 15 diameters.

at least in so far as soundings are concerned, which is unequalled by any survey hitherto made of an ocean tract.

The chief interest as regards depths centres about the region between Guam and Midway Islands. About half-way between the two a plain more than 3000 fathoms from the surface is interrupted by what is apparently a range of mountains, extending over three degrees "of longitude, and rising in places to 720 fathoms from the surface. From the western limit of the plain, some 300 miles from this mountain range, the contour is quite irregular until Guam is reached. Extensive detours to north and south of the direct course showed a mountainous region, with peaks rising to 689 fathoms below sea-level and valleys descending to a depth of more than 5000 fathoms. Four soundings below the 5000-fathom line were made in an abyss to which the name "Nero Deep" was given, with the record of 5070, 5 I0I, 5160 , and 5269 fathoms. The last sounding is, of course, the deepest on record, being only 66 feet less than 6 statute miles. Its position was lat. $12^{\circ} 43^{\prime}$ I $5^{\prime \prime}$. N., long. $145^{\circ} 49^{\prime}$ E., or 75 miles E.S.E. of the island of Guam.

From Guam to Yokohama the soundings indicated a continuous range of mountains connecting the Ladrone Islands with the Bonin group.

Another result of importance obtained by the Nero is the discovery of diatom ooze as a bottom deposit in tropical waters. Many distinct patches of characteristic diatom ooze were found on the line, especially between Guam and Luzon. Along a line about 300 miles in length, lat. $14^{\circ} 28^{\prime}$ to $14^{\circ} 50^{\prime} \mathrm{N}$., and long. $136^{\circ}$ to $130^{\circ} 30^{\prime} \mathrm{E}$, diatom ooze was brought up at thirteen stations from depths between 2432 and 3547 fathoms. Again, between Guam and Midway Islands ooze of a similar kind was obtained at three stations. In all the specimens examined the diatoms belong almost exclusively to a single species, identified by Prof. Mann as Coscinodiscus rex, Wallich. We reproduce the figure given in the plates accompanying the paper of "diatom ooze from station 746 (lat. $14^{\circ} 24^{\prime}$ N., long. $135^{\circ} 31^{\prime}$ E.), 2788 fathoms. Magnified $\mathrm{I}_{5}$ diameters."

We are unable to do more than direct attention to the two most remarkable discoveries made by this expedition. It is scarcely necessary to add that the table of 2074 soundings, with details of bottom deposits, and a large number of temperature observations, forms in itself an even more valuable contribution to oceanography than the two "records" we have mentioned.

\section{AGRICULTURAL RESEARCH IN INDIA. ${ }^{1}$}

$T$ HE publication of the first annual report of the Imperial Department of Agriculture of India is little short of an epoch-marking event. As I have said elsewhere, agricultural research has not been wholly neglected in India in the past. Much excellent work has been done by able men working under conditions which were never encouraging. But it has been fitful and uncoordinated, and always at the mercy of uninstructed and unsympathetic officials, whose one canon of criticism has been the solvency of the annual balance-sheet.

India now possesses what it may be hoped before the century has run out will be regarded as the Rothamsted of the East; and the characteristic irony, I might almost say cynicism, of the British race is content that it should owe its foundation in great part to the large-minded munificence of an American gentleman.

The outcome will not be found to-day or to-morrow, but only after years of patient work. The Government of India must not be impatient for immediate results or querulous about current expenditure. That must needs be capital invested, and the return will be the eventual increase of the wealth and prosperity of the population of India.

It now possesses for the first time a real agricultural "headquarters staff." The various experts charged with particular features of the biological campaign are no longer scattered, but are brought together in one institution, where they can work in sympathetic partnership. A glance through the pages of this report is sufficient to reveal the enormous area of the field before them. It may be prudent at the start to make a sustained attack on a few problems rather than to nibble at many.

\section{W. T. Thiselton-Dyer.}

1 Annual Report of the Imperial Department of Agriculture for the year ryo4-05. (Calcutta: Government Central Press, igo6.) Price is. $2 d$. No. I 903 , VOL. 73] 